\title{
O gênero canção em livros didáticos de literatura e língua portuguesa ${ }^{1}$
}

\author{
Sílvio Rodrigo de Moura Rocha (Sílvio Ramiro)*
}

\section{Resumo}

Este artigo se insere na discussão sobre o ensino de língua e literatura, tendo em vista que visa a discutir o papel do gênero canção na sala de aula e analisar coleções didáticas disponíveis no mercado contemporâneo brasileiro. Ademais, e a partir disso, ensaiamos propor percursos possíveis com a canção em situações de ensino-aprendizagem, sobretudo no ensino médio. Nosso objetivo alinha-se, pois, tanto às diretrizes e às pesquisas que hoje balizam o ensino de língua portuguesa e literatura, considerando-se o enfoque no ensino a partir dos gêneros textuais e da formatação estética dos textos, quanto a um lugar sociocultural que a canção ocupa em nosso país, sendo um gênero importante para a formação da identidade nacional.

Palavras-chave: Ensino. Livro didático. Literatura. Gênero textual. Canção.

1 Este trabalho é fruto de pesquisa de doutorado financiado pela Fundação de Amparo à Pesquisa de Minas Gerais (FAPEMIG).

* Doutor em Literaturas de Língua Portuguesa pela Pontifícia Universidade Católica de Minas Gerais (PUC Minas). Professor de Literatura, Língua Portuguesa e Artes da Universidade Federal de Viçosa, campus Florestal. 


\title{
The genre "song" in literature and Brazilian Portuguese textbooks
}

\begin{abstract}
This paper is within the discussion about language and literature teaching, considering that it discusses the genre "song" role in classrooms and analyze textbooks collections currently available in Brazilian market. Therefore, and from that, we purpose possible ways to use songs in teaching and learning situations, especially in high school level. Our aim align, then, to the guidelines and researches that, nowadays, determine literature and Brazilian Portuguese teaching, considering the approach in teaching taking into account the genres and the texts layout and the sociocultural place songs occupies in our country, being an important genre to national identity formation.
\end{abstract}

Keywords: Teaching. Textbooks. Literature. Genre. Song.

Recebido em:12/02/2020

Aceito em: 25/05/2020 


\section{Introdução}

Nas últimas décadas, os estudos em torno das práticas com a língua no ambiente escolar tomaram novos rumos e levantaram sérias discussões nos meios acadêmicos, sobretudo considerando os trabalhos com os gêneros textuais em sala de aula. Ao mesmo tempo em que essas mudanças ocorreram, diversos documentos oficiais surgiram no campo da educação, como os Parâmetros Curriculares Nacionais (PCN, 2000), as Orientações Curriculares para o Ensino Médio (OCEM, 2006) e, mais recentemente, a Base Nacional Comum Curricular (BNCC, 2018) e as Diretrizes Curriculares Nacionais para o Ensino Médio (DCNEM, 2018), estabelecendo percursos possíveis para o trabalho docente a partir de conceitos importantes dos estudos da linguagem. Nesse sentido, não é raro encontrarmos, nesses documentos, menções a expressões como "gêneros textuais/discursivos", "função sociocomunicativa", "letramento", "multiletramentos", "letramento literário", entre tantos outros conceitos que surgem à medida que se adensam as pesquisas no campo dos estudos linguísticos e literários. Outrossim, esses documentos, bem como os diversos trabalhos da área têm insistido muito na importância da diversidade de gêneros textuais na sala de aula, promovendo práticas de ensino-aprendizagem situadas sóciohistoricamente, rompendo com a antiga e duradoura tradição de ter como sinônimo de ensino de língua o ensino de gramática ou como sinônimo de ensino de literatura o ensino dos estilos de época.

Nesse contexto, este artigo se insere na discussão sobre o ensino de língua e literatura, tendo em vista que visa a discutir o papel do gênero canção na sala de aula e analisar coleções 
didáticas disponíveis no mercado contemporâneo. Ademais, e a partir disso, ensaiamos propor percursos possíveis com a canção em situações de ensino-aprendizagem. Nosso objetivo alinha-se, pois, tanto às diretrizes e pesquisas que hoje balizam o ensino de língua portuguesa e literatura quanto a um lugar sociocultural que a canção ocupa em nosso país, sendo um gênero importante para a formação da identidade nacional.

Mais do que admitir esse lugar tão importante da canção no cotidiano brasileiro, cremos ser esse gênero importante instrumento da prática pedagógica nos espaços escolares, pela sua fácil penetração no universo dos jovens, pelo modo despretensioso como a juventude constrói o conhecimento e pela sua natureza multissemiótica. Ademais, com Costa (2010), defendemos que a canção seja reconhecida por sua integridade como um "gênero autônomo", considerando a interseção entre letra, melodia, ritmo e harmonia.

\section{A canção como gênero textual}

A complexidade constitutiva da canção coloca-nos diante de um problema quando esse gênero protagoniza momentos de formação nas escolas brasileiras. Esse dilema instaura-se em função do seu duplo processo de construção, a partir da união de letra com melodia. De um lado, estamos diante de um estrato da canção (o verbal) que é largamente estudado nos cursos de Letras, por meio de teorias sobre a linguagem no campo da Linguística e da Literatura. De outro, deparamo-nos com outro estrato (o musical) que é estudado nos cursos de música, relativamente às melodias. Assim, forma-se um hiato que, a priori, parece difícil de ser transposto, uma vez que os professores formados nos cursos 
de letras não estariam aptos a considerar os aspectos musicais que envolvem a construção de uma canção, o que justificaria o fato de haver uma predileção pelo trabalho pedagógico com as letras das canções, em detrimento de seus aspectos musicais. No entanto, se a gênese da canção se pauta pela união de letra com melodia, omitir esse elo significa justamente tirar da canção o que particulariza a sua autonomia como gênero.

Com Luiz Antônio Marcuschi (2010), podemos dizer que "os gêneros textuais se constituem como ações sociodiscursivas para agir sobre o mundo e dizer o mundo, constituindo-o de algum modo" (MARCUSCHI, 2010, p. 23). Assim, ao mesmo tempo em que os gêneros são construtos sociais, dos quais toda a sociedade se utiliza para agir e dizer sobre o mundo, os gêneros, na escola, também assumem um lugar que é de objeto de ensinoaprendizagem, a partir das funções que esses textos exercem no ambiente de que fazem parte. Nesse sentido, o hiato de que tratamos há pouco precisa ser também transposto pela escola, pois a canção é um gênero utilizado em sala e, sendo assim, deve penetrar nessa instituição de ensino tendo em vista o modo como ele se constrói, como age e como diz sobre o mundo.

Como afirma Bronckart, "a apropriação dos gêneros é um mecanismo fundamental de socialização, de inserção de práticas nas atividades comunicativas humanas" (BRONCKART apud MARCUSCHI, 2010, p. 31). Essa noção sociointeracionista da língua é assumida por Bronckart e, segundo Marcuschi, "pela maioria dos autores que tratam a língua em seus aspectos discursivos e enunciativos, e não em suas peculiaridades formais" (MARCUSCHI, 2010, p. 23). Por isso, é preciso considerar que "eles são eventos linguísticos, mas não se definem por características linguísticas: caracterizam-se enquanto atividades 
sociodiscursivas" (MARCUSCHI, 2010, p. 30-31). Bronckart (1999) e Marcuschi (2010), então, tomam o gênero textual como objeto de ensino, reinterpretando a teoria bakhtiniana para colocá-la no centro da discussão sobre o ensino de língua. Nesse sentido, se a língua é fruto da prática social e, se essa prática se materializa por meio de gêneros textuais, é papel da escola abrir espaço para o ensino a partir dos gêneros, que, além das "peculiaridades formais", possibilitam o estudo do "discurso" e da "enunciação", considerando as finalidades sociointerativas dos textos. Para que isso ocorra, é importante que os estudantes, além de se apropriarem dos gêneros, também tomem consciência de sua constituição, do modo como participam das atividades humanas em que desempenham suas funções cotidianas.

Nesse ponto, mais especificamente, podemos trazer alguns tópicos sobre os gêneros com os quais Marcuschi (2008) opera e que são importantes para este trabalho. Segundo o autor, os gêneros são entidades:
a) dinâmicas;
b) históricas;
c) sociais;
d) situadas;
e) comunicativas;
f) orientadas para fins específicos;
g) ligadas a determinadas comunidades discursivas;
h) ligadas a domínios discursivos;
i) recorrentes;
j) estabilizadas em formatos mais ou menos claros. (MARCUSCHI, 2008, p. 159).

Nesse mesmo texto, Marcuschi afirma que os "gêneros são formas textuais escritas ou orais bastante estáveis, histórica e socialmente situadas" (MARCUSCHI, 2008, p. 155), "mas por outro lado [são] um convite a escolhas, estilos, criatividade e 
variação" (MARCUSCHI, 2008, p. 156). Essa conceituação é possibilitada pelos tópicos propostos pelo autor, à medida que o reconhecimento da situação comunicativa e o pertencimento a certos domínios discursivos é fundamental para o formato que o gênero assume; do mesmo modo, os fins específicos de cada gênero, bem como as intenções de seu produtor podem dinamizar e relativizar algumas marcas, considerando uma abertura para a variação e atualização dos gêneros em práticas situadas.

Nesse sentido, em um segundo momento, referimo-nos ao que Tatit (1997), no campo dos estudos da semiótica da canção, designa de "compreensão global de uma gramática" (TATIT, 1997, p. 101). Para exemplificar isso, o autor afirma que

é comum alguém dizer que ouviu um samba de Tom Jobim, um rock dos Titãs ou mais uma canção romântica de Roberto Carlos. Todas essas designações de gênero denotam a compreensão global de uma gramática. Significa que o ouvinte conseguiu integrar inúmeras unidades sonoras numa sequência com outras do mesmo paradigma. Sambas, boleros, rocks, marchas... são ordenações rítmicas gerais que servem de ponto de partida para uma investigação mais detalhada da composição popular. (TATIT, 1997, p. 101).

Essa citação de Tatit demonstra que há "unidades sonoras" que são mais comuns a um ou outro (sub)gênero de canção, porque são mais recorrentes nos boleros, nos sambas, no rocks, nas marchas etc. Interessante que o ouvinte reconhece essas unidades e, dado o contexto em que se situa, admite como plausível ou não esta ou aquela "gramática" sonora, esta ou aquela "ordenação rítmica", em função de promover relações entre o contexto e o texto produzido ou, nos termos de Marcuschi (2008), entre os "domínios discursivos" e os "formatos" do gênero. Esse reconhecimento por parte do 
ouvinte comprova o fato de que os gêneros são formas textuais estáveis, histórico e socialmente situadas, ainda que permitam variações e atualizações.

Nesse contexto, temos de partir do pressuposto de que a canção, ao integrar unidades sonoras e ordenações rítmicas, o faz unindo também enunciados verbais aos percursos melódicos de sua construção estética. Obviamente, ao buscarmos essa gramática de construção dos gêneros, não pretendemos enrijecer a análise do texto nem esgotar os possíveis caminhos interpretativos. É por isso que, analisando cada canção, consideramos sua situação comunicativa, seu domínio discursivo, sua formatação, para estabelecermos os elos entre o plano verbal e o musical, a fim de que a integração entre as partes possa ser compreendida como fundamental à análise do gênero.

\section{A canção em livros didáticos}

A despeito de nossa vivência em um mundo marcado pelas multissemioses, pela multiplicidade de ferramentas dos espaços virtuais e pelo intenso contato da juventude com os recursos tecnológicos, os livros didáticos, sobretudo no ensino público, ainda ocupam um lugar de destaque entre os recursos para os momentos de ensino-aprendizagem. No caso da rede pública brasileira, esses livros são distribuídos gratuitamente pelo Estado, mediante um processo avaliativo que o próprio governo financia a fim de que as escolas e os professores possam escolher as coleções mais adequadas para o ensino, de acordo com cada segmento e componente curricular.

Desde as primeiras páginas do Guia de livros didáticos (2014), publicado pelo Ministério da Educação, fica evidente 
a sua preocupação com a inserção dos manuais e do ensino de língua portuguesa no contexto em que estão incorporados também os discentes. Considerando que se trata de um guia para o ensino médio (EM), a filiação dos estudantes à "juventude" é bastante reiterada no documento, que considera a necessidade de uma interlocução em sala de aula que se paute pela legitimação das características dessa fase da vida dos discentes, que são distintos daqueles do ensino fundamental (EF). Segundo afirma o Guia, em relação aos estudantes do EM, "uma das características socialmente relevantes do aprendiz desse nível, em situação escolar regular, é o seu pertencimento à juventude" (BRASIL, 2014, p. 9).

No caso do ensino de língua portuguesa, conforme o documento, as especificidades da juventude, então, devem conduzir as escolhas que os livros didáticos e os professores fazem, bem como as metodologias e os instrumentos que utilizam no contexto escolar. Nesse sentido, os gêneros textuais selecionados para o ensino serão pautados por essa condução, considerando competências e habilidades que não só são demandadas por e para essa faixa etária, mas também pelo meio sociocultural em que os jovens estão inseridos:

Entre essas formas de expressão, são particularmente relevantes as práticas não escolares de letramento e os gêneros (como as letras de rap e de canções, os fanzines, os grafites, os manifestos, gêneros que circulam em redes sociais etc.) próprios da juventude, assim como os gêneros que, por sua destinação comercial, dirigem-se privilegiadamente a essa faixa da população (quadrinhos comerciais, suplementos juvenis da imprensa diária, revistas direcionadas etc.). (BRASIL, 2014, p, 10 - grifos nossos).

É interessante notar que o Guia propõe um equilíbrio entre as práticas de letramento escolar e as de letramento não escolar. 
Dessa forma, o documento deixa nítida a necessidade de a escola servir, ao mesmo tempo, como estímulo a novas práticas de letramento, mas também como instituição legitimadora da cultura que o jovem traz dos espaços extraescolares com os quais convive. Assim, o Guia também frisa a expressiva presença, na rede pública de ensino, de um tipo de jovem egresso de camadas populares, o que enseja a relevância da valorização de formas de expressão próprias da juventude desse contexto (BRASIL, 2014).

Relevantetambém salientarque, neste trabalho, defendemos, com Candido (2012), o poder humanizador dos textos estéticos, pelo fato de sua organização interna propiciar, pelos percursos de leitura, análise e interpretação, a organização mental do leitor. Para Candido, o texto impressiona porque sua possibilidade de impressionar foi determinada pela ordenação recebida de quem o produziu. Em palavras usuais: o conteúdo só atua por causa da forma, e a forma traz em si, virtualmente, uma capacidade de humanizar devido à coerência mental que pressupõe e que sugere: "o caos originário, isto é, o material bruto a partir do qual o produtor escolheu uma forma, torna-se ordem; por isso, o meu caos interior também se ordena e a mensagem pode atuar" (CANDIDO, 2012, p. 27).

Ao analisarmos o tratamento dado à canção em obras de caráter didático e ainda defendermos sua participação nos processos de letramento escolar, estamos, pois, partindo desse pressuposto de que o texto tem uma forma, uma ordem, justamente porque temos defendido que ele se organiza a partir de uma lógica interna que propicia a organização do caos interior do leitor. Toda obra literária, para Candido (2012), pressupõe a superação de um caos, à medida que forma e conteúdo se 
amarram e, assim, processualmente, o leitor também amarra as ideias que vão se formando, tanto em relação à própria obra quanto em relação à sua mente, a qual, paulatinamente, dá forma ao seu conteúdo inconsciente. Em nosso caso, em se tratando de textos que imbricam materialidade verbal e musical, o acesso à integridade da canção e à sua organização é de suma importância para que esse gênero textual funcione como estrutura organizada em prol da humanização de cada estudante que frui esse objeto artístico.

Nesse contexto, passaremos, então, a analisar como se dá a inserção das canções nos livros didáticos de língua portuguesa e literatura para o ensino médio. ${ }^{1}$ Assim, a partir da lista de livros aprovados no Programa Nacional dos Livros Didáticos (PNLD) 2015-2017, selecionamos duas coleções que, desde a primeira edição do PNLD-EM (2006), estão aprovadas no Programa e que, além disso, foram as mais requisitadas pelos professores da rede pública. A obra Português: linguagens, de William Roberto Cereja e Thereza Cochar Magalhães, foi a mais distribuída pelo Fundo Nacional de Desenvolvimento da Educação (FNDE), com 2.313.339 exemplares distribuídos às escolas. Em segundo lugar, está a coleção Novas palavras, de Emília Amaral, Mauro Ferreira, Ricardo Leite e Severino Antônio, com um total de 1.548.498 unidades distribuídas para a rede pública de ensino. O PNLD 2015-2017 aprovou 10 obras para o ensino médio, e as duas obras analisadas foram responsáveis por mais de $50 \%$ da quantidade de unidades distribuídas; todas as outras 8 obras somam, juntas, 3.706.366 exemplares. Esses números representam a expressividade das duas coleções para o ensino de

1 Destacamos que, pela extensão deste trabalho, faremos um recorte na análise feita a partir dos manuais didáticos, tratando dos capítulos da unidade 1 das duas obras. Além disso, optamos por descrever os capítulos das obras, sem inserir as imagens de suas páginas, dada a impossibilidade de estampá-las neste artigo, novamente em função do seu reduzido número de páginas. 
língua portuguesa no ensino médio brasileiro, somando, juntas, 3.861.837 exemplares. Com esses dados, podemos concluir que mais de $50 \%$ dos discentes do ensino médio público foram educados, entre 2015 e 2017, formalmente, em língua portuguesa e literatura, com as duas coleções aqui selecionadas, revelando o impacto desses manuais no contexto escolar brasileiro. ${ }^{2}$ Nesse sentido, mostra-se relevante uma análise que se debruce sobre essas coleções e sobre o percurso que elas propõem ao utilizarem a canção como gênero textual eleito para o letramento no ensino médio, conforme faremos a seguir.

Importante destacar, já de início, que, nas duas coleções analisadas, não encontramos nenhum capítulo que seja, exclusivamente, dedicado à canção, embora vários deles utilizem-na com os mais variados objetivos. Aliás, as duas coleções dedicam-se, especificamente, ao trabalho com gêneros textuais apenas nos capítulos destinados à produção de textos, nomeados, nas obras Português: linguagens e Novas Palavras, respectivamente, de "Produção de texto" e "Redação e leitura". Vale frisar, ainda, que ambas as obras são divididas em partes que contemplam os conteúdos de literatura, produção textual, interpretação de textos e gramática, como acontece, em geral, com os livros didáticos de língua portuguesa. Essa simples organização das obras já deixa entrever uma desintegração das componentes de língua portuguesa, o que enseja também aulas que serão dedicadas, separadamente, a cada uma dessas componentes. No caso específico dos capítulos ligados à literatura, eles são organizados de acordo com uma lógica historiográfica, de modo cronológico e sequenciado pelas

\footnotetext{
2 Embora o recorte temporal desta pesquisa seja relativo ao PNLD 2015-2017, frisa-se que as duas coleções analisadas continuam presentes no PNLD aprovado para o triênio 2018-2020 e mantém-se ainda em ampla distribuição para as escolas públicas brasileiras.
} 
chamadas escolas literárias, desde o Trovadorismo português até o Modernismo brasileiro. Embora não seja esse o nosso objeto de pesquisa, cremos que seja um equívoco a permanência dessa metodologia de ensino, tendo em vista que a literatura é uma disciplina de formação, e não de informação, como defende o professor Antonio Candido (2012). Nesse sentido, não basta só reconhecermos esse problema posto, mas também é necessário procurar caminhos para superá-lo, a fim de que o caráter estético $\mathrm{e}$, consequentemente, humanizador da literatura seja reconhecido e, além disso, fruído em sala de aula pelos estudantes e pelos professores, sendo um elemento transformador do sujeito-leitor e, por consequência, da sociedade.

$\mathrm{Na}$ obra de Cereja e Magalhães, a página de abertura do primeiro capítulo da unidade 1 tem uma pequena seção intitulada "Ouça", o que já evoca algum gênero de natureza sonora, provocando no leitor seu sentido auditivo. Confirmando essa evocação, a seção sugere canções relacionadas ao Trovadorismo, tema da primeira unidade, ao lado de variedades linguísticas, teoria da comunicação e figuras de linguagem, por exemplo. Como na unidade 1, todas as outras trazem esse box indicando canções conectadas ao tema; no entanto, não passam de indicações, com curtas frases contextualizando a sugestão. Ao longo das unidades, não são retomadas as canções nem são feitas orientações de leitura para que elas possam se conectar aos textos selecionados nas páginas internas.

O capítulo 5, no interior da unidade 1, trata das cantigas medievais, que, segundo os autores, "eram canções criadas e cantadas por poetas chamados trovadores" (CEREJA e MAGALHÃES, v. 1, 2013, p. 62). Interessante notar que, na abertura do capítulo, o verbo "cantar" refere-se à canção, 
conectando-a, portanto, ao mundo da música. No entanto, ao longo do capítulo, as canções, da página 63 à 67, não exploram nem mencionam o fato de, à época, não existir a separação que hoje há entre a poesia e a canção - estando a primeira ligada ao mundo da escrita e a segunda, ao mundo da oralidade cantada. $\mathrm{O}$ capítulo, que é curto (com apenas 6 páginas), prende-se mais à organização da sociedade medieval e à projeção dessa sociedade no discurso das canções, explorando as relações de vassalagem, a convenção amorosa e o papel da mulher na canção e na vida real.

A despeito disso, há um tópico, na página 64, que se dedica mais à linguagem (o que é, nesse ponto, consonante com o título do capítulo - "A linguagem do Trovadorismo"), pois trata dos paralelismos, denominados de leixa-pren. Nesse ponto, inclusive, é importante ressaltar que se exploram, rapidamente, características típicas de canções, como a função dos paralelismos para a memorização por parte do público, até porque os poemas são gêneros, originalmente, orais: "A cantigas eram cantadas e dançadas e os paralelismos contribuíam para a memorização do texto" (CEREJA e MAGALHÃES, 2013, p. 64).

Nesse ponto, ressaltamos que o capítulo deixa de explorar a canção (no caso, as cantigas medievais) como um gênero com particularidades que são de sua natureza. Embora haja a exploração da musicalidade, isso se pauta na sonoridade da letra da canção lida, e não cantada, porque não há links para que o estudante possa ter contato com o canto. Seria interessante, por exemplo, nessa parte, a retomada da seção que há na página de abertura da unidade 1, a qual sugere os discos "Musikantiga I" e "Cantigas de amigo", de La Bataglia, a fim de que se faça jus à constituição intersemiótica das cantigas, aliando a letra 
impressa no livro à versão cantada que está disponível nos discos sugeridos. Na verdade, o primeiro disco contém músicas instrumentais (sem letra), enquanto o segundo é que, de fato, reúne o gênero cantiga. Além desses discos, o box também aponta para os álbuns de Elomar, famoso artista brasileiro que se inspira nas cantigas medievais para produzir suas canções regionais.

Já na obra Novas Palavras, o capítulo 3 é nomeado de "O Trovadorismo" e inicia-se com uma iluminura do códice de Manesse, de 1340, ao lado de uma prosa-poética de Dora Ferreira da Silva, que é uma espécie de releitura da iluminura. Duas páginas à frente, aparece a primeira cantiga trovadoresca, de Estevam Coelho, a qual vem parafraseada ao lado, em português moderno, e intertextualiza-se, tematicamente, com a iluminura e a prosa-poética, pelo fato de apresentar uma moça que se distrai do sofrimento amoroso, enquanto borda. $\mathrm{O}$ capítulo explora apenas a leitura dessa canção, sem indicar a audição; no entanto, faz menção ao fato de ela ter sido composta para ser cantada em público, "como muitas canções populares de hoje", possuindo "estrutura repetitiva que acentuava o seu ritmo, facilitava a memorização e intensificava a expressão dos sentimentos" (AMARAL et al., 2013, p. 43). As questões que o capítulo propõe requerem que o estudante consiga interpretar a letra de acordo com a temática do amor inalcançado e, além disso, exigem que se faça um esquema que represente as repetições dos versos, ressaltando que "a repetição é um dos procedimentos expressivos da poesia e da música popular" (AMARAL et al., 2013, p. 44).

Consideramos importantes os dois fios que balizam as questões propostas pela obra, considerando a temática (ligada 
às marcas socioculturais da época em que o texto se insere) e a estrutura (relacionada às características de textos cancionais). Julgamos, sobretudo, ser muito pertinente explorar as repetições como peculiaridades dos textos poéticos e cancionais, tendo em vista que essas estratégias são fundamentais para a riqueza estética e, principalmente, para a musicalidade desses textos. Por outro lado, como não se trata de um poema, visto que há, na origem dos textos, o estrato musical vinculado à letra, seria de suma importância que, de algum modo, a obra remetesse à melodia da cantiga. Essa remissão estaria, até mesmo, reafirmando o que a própria obra diz sobre o fato de as cantigas serem feitas para uma expressão cantada em público. Nesse sentido, assim como a obra de Cereja e Magalhães, a de Amaral et al. deixa uma lacuna ao considerar o gênero cantiga trovadoresca, relativamente à melodia das cantigas e ao elo entre essa melodia e a letra do texto.

Nas duas obras analisadas, as peças do cancioneiro brasileiro também estão distribuídas ao longo dos diversos capítulos, tanto ligadas às seções de literatura, quanto às de gramática, interpretação e produção de textos, dadas as subdivisões de cada coleção. A coleção de Cereja e Magalhães é organizada, em seu primeiro volume, em quatro unidades, as quais são subdivididas em capítulos. A primeira unidade da coleção é a que mais conta com canções em sua coletânea de textos a serem trabalhados. Isso se deve, principalmente, pelo fato de ser a unidade em que, dado o estudo cronológico da literatura, as cantigas medievais estão presentes. Assim, para este trabalho, estamos considerando as cantigas medievais em nosso escopo de canções (conforme visto anteriormente), embora façamos a distinção entre elas e as canções populares, as quais, em nosso caso, são dos séculos XX e XXI. 
A canção inserida na página 21 , do manual de Cereja e Magalhães, é “Ana de Amsterdam”, de Chico Buarque. Nessa página, ela apenas cumpre o papel de exemplificar a diferença entre a voz do eu lírico e a voz do escritor, reiterando-se que, embora seja de autoria de um autor masculino, a voz lírica do texto é feminina, o que ocorre em outras várias canções de Chico Buarque, como "O meu guri”, cuja seleção lexical, por exemplo, denuncia a dicção feminina da canção. Nota-se, no box no qual uma estrofe é inserida, que a presença da canção procura ilustrar o título "Eu lírico: a voz do poema", o que revela o fato de a obra tratar o gênero poema em igual condição ao gênero canção.

$\mathrm{Na}$ mesma unidade, no capítulo 4, intitulado "O poema", os autores utilizam diversas canções também de Chico Buarque para ilustrar os recursos musicais presentes em poemas (métrica, ritmo, rima, assonância, aliteração, paronomásia e paralelismo). É curioso o fato de esse capítulo 4, dentre todos os outros da obra, ser aquele que mais conta com a presença de canções, excetuando-se os capítulos sobre as cantigas, por sua particularidade em relação às produções do Trovadorismo, como já frisamos. Ainda assim, o capítulo 8, específico sobre o Trovadorismo, conta com 7 cantigas, enquanto o capítulo 4 conta com 6 canções populares e nenhum poema, mesmo que seja intitulado de "O poema".

A utilização dessas canções, nesse capítulo, corrobora o que dissemos sobre o capítulo 1, o qual revelava que os autores tratam poema e canção como gêneros equivalentes, por carregarem a musicalidade de que o capítulo trata. Vale dizer que não há o impeditivo de que, inicialmente, algum trabalho com o gênero canção se dê a partir da letra, como ponto de partida para acessar o todo constitutivo do gênero; porém o que nos chama 
a atenção é o fato de apenas a letra ser explorada. Não é de se estranhar, nessas circunstâncias, que um capítulo seja nomeado de "O poema", e não de "A canção", apesar de ele privilegiar apenas canções em sua coletânea de textos e, exclusivamente, as de Chico Buarque.

A obra Novas Palavras, de Amaral et al., subdivide-se em 3 partes: i) Literatura; ii) Gramática; iii) Redação e Leitura. Entretanto, diferentemente da obra Português: linguagens, de Cereja e Magalhães, as unidades são separadas conforme essas componentes, sendo uma unidade para literatura, uma para gramática e outra para redação e leitura, de modo bastante isolado. Desse modo, iremos, inicialmente, pela própria organização da obra, explorar a primeira unidade que nela aparece, a de literatura.

Nessa unidade da coleção, a aparição de canções está praticamente restrita aos capítulos relacionados ao período do Trovadorismo, com raras outras duas, uma no capítulo 4, sobre Humanismo (com um poema intitulado "Cantiga"), e outra no capítulo 6, sobre o Quinhentismo. A página 43 refere-se ao fato de a "Cantiga" ser "cantada em público, como muitas canções populares de hoje"' (AMARAL et al, 2013, p. 43); contudo não abre espaço, nas páginas do capítulo, para uma experiência estética mais densa com as multissemioses desse gênero. $\mathrm{Na}$ página 47, um box remete às "reconstituições das cantigas, realizadas por grupos especializados em música medieval, e até coreografias criadas a partir da obra de Martim Codax, como as do Grupo Corpo para o balé chamado "Sem mim" (AMARAL et al., 2013, p. 47). Apesar de esse box colocar o estudante em contato com o gênero cantiga em sua integridade, não há um processo de mediação dessa experiência, uma vez que não há atividades ou percursos sugeridos que possam nortear o contato entre o ouvinte e a obra. 
Esse box traz uma sugestão para que o estudante procure o site onde pode encontrar as cantigas e suas adaptações; assim, essa estratégia, embora provocativa, parece-nos arriscada, pelo fato de possibilitar que a canção seja mero pretexto para um momento de entretenimento - além de não ser mediado pelo contato com o docente. Por outro lado, podemos perceber a escolha interessante do título do box, "Navegar é preciso", considerando a potencialidade intertextual que nele está, dialogando com os famosos versos de Fernando Pessoa, apesar de não haver, de fato, esse estímulo à "navegação", no sentido de descoberta. É por esse tipo de estratégia, com pouco estímulo à "navegação", à pesquisa, que temos defendido, neste trabalho, ser preciso considerar a integridade do gênero para que ele chegue aos ambientes de ensino com a potencialidade semiótica que lhe é constitutiva e fundamental, a fim de que não se corra o risco para o qual Nelson Barros da Costa nos alerta: a transformação da canção em "espaço de lazer, mais do que um espaço de aprendizado" (COSTA, 2010, p. 131).

\section{Uma canção de Lenine no livro didático}

O que podemos perceber, ao analisar as coleções didáticas, é que os recursos estéticos que constroem uma canção e um poema, por serem os mesmos, parecem ser suficientes para que os autores dos manuais didáticos coloquem os dois gêneros em igualdade de condições, como se a letra de uma canção fosse o mesmo que um poema. Para ilustrar e explorar esse problema, trazemos uma canção de Lenine que foi parte de nosso trabalho de mestrado e que também figura nas páginas de uma coleção didática: 


\section{Meu amanhã}

Ela é minha delícia

O meu adorno

Janela de retorno

Uma viagem sideral

Ela é minha festa

Meu requinte

A única ouvinte

Da minha Rádio Nacional

Ela é minha sina

$\mathrm{O}$ meu cinema

A tela da minha cena

A cerca do meu quintal

Minha meta, minha metade

Minha seta, minha saudade

Minha diva, meu divã

Minha manha, meu amanhã

Ela é minha orgia

Meu quitute

Insaciável apetite

Numa ceia de natal

Ela é minha bela

Meu brinquedo

Minha certeza, meu medo

É meu céu e meu mal

Ela é o meu vício

E dependência

Incansável paciência

E o desfecho final

Minha meta, minha metade

Minha seta, minha saudade

Minha diva, meu divã

Minha manha, meu amanhã 
Meu fá, minha fã

A massa e a maçã

Minha diva, meu divã

Minha manha, meu amanhã

Meu lá, minha lã

Minha paga, minha pagã

Meu velar, minha avelã

Amor em Roma, aroma de romã

O sal e o são

O que é certo, o que é sertão

Meu Tao, e meu tão

Nau de Nassau, minha nação

(LENINE, 1999)

A letra dessa canção, mesmo não sendo cantada, já carrega uma alta dose de musicalidade, derivada da sequência de paronomásias, aliterações e assonâncias que sugerem uma sonoridade bastante peculiar. Isso é bastante condizente com a ideia de Lenine, reiterada por ele em diversas entrevistas e documentários, de que a língua portuguesa brasileira é dotada de um relevo sonoro que lhe é muito caro, por isso ele aposta muito nesse tipo de construção musical na letra de suas canções. ${ }^{3}$ No entanto, não é simplesmente pela musicalidade da letra que podemos dizer que estamos diante de uma canção ou de um poema; não basta esse tipo de marca constitutiva do texto para que ele possa ser categorizado.

A coleção didática de Cereja e Magalhães, por exemplo, utiliza essa canção, "Meu amanhã", de Lenine, em sua unidade 2. Ela vem inserida no capítulo 2, cujo foco é o estudo do gênero

\footnotetext{
3 No documentário "Palavra (En)cantanda", Lenine diz: pelo fato de vir, há alguns anos, pulverizando o que eu faço pelo mundo e isso tem sido o pretexto mais bacana de tudo que eu faço, que é poder viajar e poder conhecer povos e culturas, eu venho confirmando isso a cada vez que eu saio, né, um tipo de relevo que a lingua brasileira, a portuguesa brasileira, tem e que adquiriu. Isso, realmente, é muito ímpar. Não só pelos tempos das palavras, né, o oxítono, o paroxítono e o proparoxítono; portanto a palavra pode ser pandandã, pandãda ou pádandan. Só essas possibilidades rítmicas são incriveis. Além disso, a gente inventou mais duas outras vogais, por exemplo, tem o a, tem o ê fechado e o é aberto, a gente tem o $\boldsymbol{i}$, o $\hat{\boldsymbol{o}}$ fechado e o $\boldsymbol{o}$ aberto e o u. São sete sons de vogais, isso também é maravilhoso. Além disso tem as coisas dos nasais, que, realmente, toda vez que eu ouço um "inho", um "em”, um "ão", é de partir o coração, acho muito bonito... risos.
} 
relato pessoal e do tipo descritivo. Na página 144, um trecho da canção aparece no exercício 7, o qual provoca o estudante a reconhecer as metáforas, recurso recorrente na letra; em seguida, propõe que o estudante produza uma descrição, em prosa ou em verso, de alguns temas postos no exercício.

Curioso perceber que o exercício abre a possibilidade de produção de um texto em verso ou em prosa, a partir de uma canção, mas não propõe qual o gênero o estudante deve produzir nem expõe marcas básicas desse gênero para tal trabalho. Ele, simplesmente, determina o tipo textual: uma descrição. Além disso, se ele parte de uma canção, que é um texto em verso, seria interessante que explorasse, para o fim didático de produção de texto, as marcas que constituem uma canção, uma vez que o estudante precisa dessas referências para materializar o gênero textual, considerando-o a partir de uma prática situada. Assim, como em outras diversas vezes, a coleção utiliza, nesse exercício, a canção como objeto de estudo, mas não cria uma situação sociodiscursiva adequada à finalidade do trabalho didático, deixando de respaldar a integridade do gênero textual.

Recurso muito interessante nessa canção de Lenine e que foi evocado por Cereja e Magalhães (2013), a metáfora é a forma estética selecionada pelo eu lírico para definir sua amada com as mais diversas características. No entanto, a coleção não verticaliza o debate sobre o que é uma metáfora nem explora esse recurso e seus efeitos em outros textos; na verdade, a coleção parece escolher a metáfora pela sua recorrência no gênero relato pessoal, objeto de estudo do capítulo em questão. O pouco que se apresenta sobre a metáfora é que ela "amplia a visualização do ser descrito, enriquece o texto e dá nova vida às palavras" (CEREJA e MAGALHÃES, 2013, p. 144). 
Obviamente, a metáfora possibilita sim esses efeitos e eles são, realmente, importantes à construção de um enunciado de caráter metafórico, mas são ainda pouco suficientes para que um estudante possa experienciar a leitura de um texto metafórico ou mesmo - e talvez, principalmente - a produção de um gênero com esse recurso em evidência.

Na própria canção de Lenine, a coleção poderia se demorar mais para explorar um recurso de linguagem tão importante à produção do texto artístico, focando o que ela mesma diz sobre a metáfora: a ampliação da visualização do ser descrito; o enriquecimento do texto; e a nova vida das palavras. Tão enriquecedor quanto a análise da metáfora na letra seria, também, a análise do modo como a melodia vocaliza esses versos metafóricos, considerando a totalidade do gênero. A coleção não tem a pretensão, pelo que percebemos na pesquisa, de explorar o estrato musical das canções que insere em suas páginas; isso, muito provavelmente, em função de ser uma obra voltada para o ensino de língua e literatura, isto é, com foco em textos de natureza verbal. Nesse sentido, faremos essa exploração do que cremos ser importante no trabalho com a metáfora, articulando uma análise da letra em sintonia com a melodia, em busca de entendermos melhor o processamento metafórico no texto.

$\mathrm{Na}$ primeira parte da canção, as metáforas da letra se constroem de modo integrado à sinuosidade da melodia, o que ocorre igualmente na primeira e na segunda estrofe.

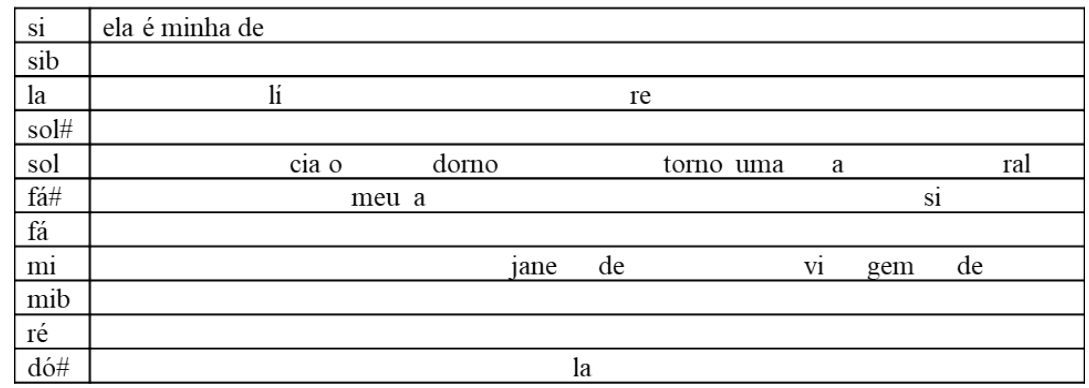


Sílvio Rodrigo de Moura Rocha (Sílvio Ramiro)

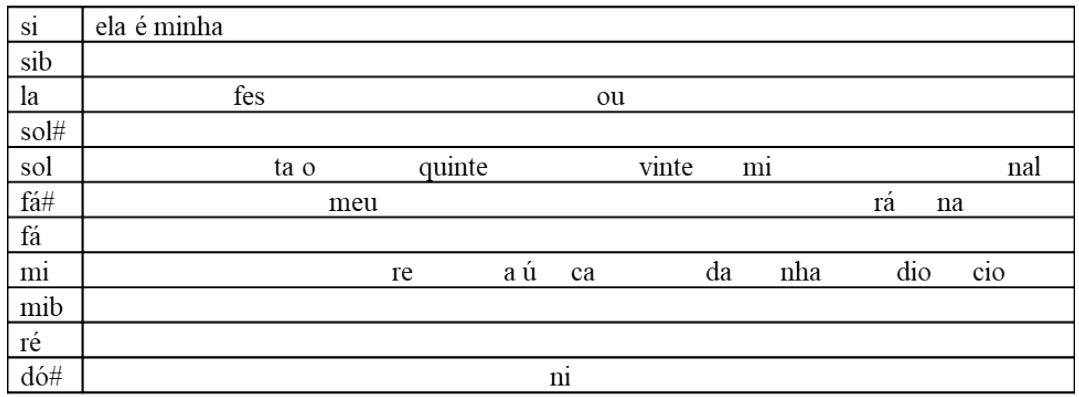

As melodias, nas duas estrofes, percorrem 5 tons, o que seria quase uma oitava inteira (6 tons), com movimentos que se serpenteiam para descrever o objeto de desejo do eu lírico. Essas melodias serpenteais demonstram uma movimentação sensual que presentifica a amada na vida do enunciador: se ela não está presente concretamente, as metáforas e as melodias substituem, estética e psicologicamente, sua presença como "delícia", "adorno", "festa", "requinte" etc.

Mais que considerar aqui a metáfora um enfeite para a construção estética, temos de considerá-la um recurso inerenteà linguagem, sem o qual a comunicação humana não se efetua. Por muito tempo, a metáfora fora tratada simplesmente como um adorno, um desvio da linguagem cotidiana e racional, presente em enunciados poéticos ou em frases do dia a dia que pretendiam ter efeitos expressivos incomuns, como os ditos populares, por exemplo, ou as expressões cristalizadas da língua. No entanto, como acentua Antonio Candido, as metáforas são "elementos viscerais da expressão" (CANDIDO, 1996, p. 70) e, vindo das vísceras, eles são fundamentais à materialização da linguagem: "na linguagem corrente, é praticamente impossível falarmos sem recorrer a este meio de expressão" (CANDIDO, 1996, p. 69). Obviamente, no texto de natureza artística, construído com essa 
finalidade estética, a metáfora surge em outro contexto, muitas vezes com o objetivo, sim, de gerar estranheza ou de causar efeitos inusitados.

Logo, retornando à canção de Lenine e à proposta de trabalho do livro didático, temos de perceber que a metáfora, na canção, também se constrói como um processamento mental, para que a mulher descrita se incorpore aos atributos que o enunciador enxerga nela, o que se liga à ampliação do ser descrito e ao enriquecimento do texto, segundo afirmam Cereja e Magalhães (2013). Sobretudo, precisamos considerar que, recebendo uma série de predicativos, a imagem mental que se faz dessa mulher é complexa, porque não pode se limitar a nenhum deles. Ela é delícia, é adorno, é janela de retorno, é viagem sideral; ela é bela, é requinte, é ouvinte da rádio nacional. Nesse caso, portanto, a metáfora tem de ser encarada não apenas como uma construção puramente linguística, como figura de linguagem; mais que isso, é um modo de ver o outro, de construí-lo por meio de um processamento mental complexo, que procura transferir, a um objeto primeiro, predicados que são de um objeto segundo. A partir disso, a imagem mental formada não é mais nem a do primeiro objeto (no caso, a mulher), nem a do segundo (delícia, adorno, requinte, ouvinte etc.): o ser formado é resultado de um mapeamento artístico e mental.

Se analisarmos com cuidado as melodias desses versos que descrevem a mulher, perceberemos que são melodias bastante sinuosas, como já indicamos. São movimentos melódicos que se serpenteiam para, juntamente com a palavra, formar a imagem que se faz do ser desejado. Tomada pelo desejo, a voz poética não apenas descreve verbalmente a mulher, mas também se apropria de um modo de expressão melódica sensual - até mesmo sexual, 
vide o movimento serpenteal que as notas musicais mimetizam. Nesse ponto, podemos dizer, então, que as metáforas da canção se projetam também nas melodias, construindo um todo de sentido que é característico da linguagem cancional, cuja natureza é intersemiótica.

Se, nas duas primeiras estrofes da canção, as melodias têm um movimento bastante sinuoso, metaforizando a sensualidade feminina, na terceira estrofe, no entanto, há a construção de outro melodia, menos movimentada, quase que somente no espectro de 1 tom, com duas pequenas fugas para a distância de 2 tons. Chama a atenção, também, o fato de essa modificação melódica acontecer concomitante ao tipo de predicação que aparece na letra da canção:

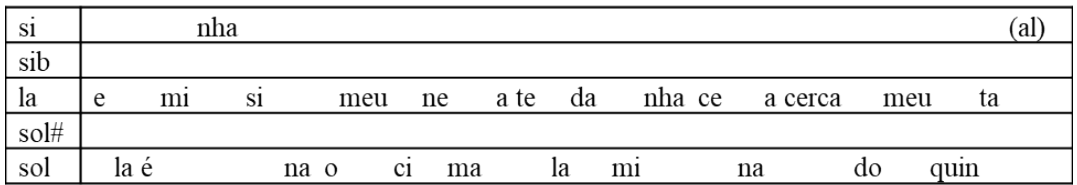

Reparemos que as metáforas são formadas a partir de "sina", "cinema", "tela da minha cena" e "cerca do meu quintal". Em todas as quatro predicações, há imagens relacionadas a ambientes fechados, diferentes, por exemplo, do "espaço sideral" e da "festa" presentes nas duas primeiras estrofes. Se, no início da canção, os movimentos melódicos sensualizam as melodias, por causa da ausência da amada, aqui as pequenas distâncias constroem uma sensação de proximidade entre o eu lírico e a mulher. As metáforas, agora, estão ligadas a espaços de limites bem definidos, a cercas que cerceiam os movimentos e promovem a união - embora a sensualidade, de certo modo, não se dissipe, por causa da presença reiterada dos sons sibilantes, portanto, também sinuosos, das palavras (sina/cinema/cena/ 
cerca). Assim, unidos, o plano verbal e o plano musical formam a interseção lítero-melódica que caracteriza o gênero canção, partindo de um processamento estético e mental que carece também de uma linguagem complexa para se expressar.

\section{Considerações finais}

Com a canção, tem-se um promissor objeto para que o letramento dos estudantes brasileiros seja enfrentado e tratado com a seriedade que esse tema enseja. Em consonância com o que preconiza o Guia dos livros didáticos do PNLD, o contato com os gêneros e os valores da juventude precisa ser considerado para que se possa motivar e atrair o estudante do Ensino Médio, respaldando-lhe os conhecimentos trazidos dos ambientes extraescolares em que circula e, ainda, propiciandolhe alcançar novos patamares no processo de letramento, por meio da educação estética.

Para isso, no entanto, defendemos que a canção precise ser considerada, conforme enfatizamos, como gênero autônomo, texto de construção complexa, de formação intersemiótica, por conjugar letra e melodia. No entanto, ao analisarmos os dois manuais didáticos, neste trabalho, percebemos que muito pouco se alcança em relação à canção como gênero lítero-musical. $\mathrm{Na}$ maioria das vezes, o que se percebe é que as canções aparecem apenas como letras, sendo tratadas pelos manuais como equivalentes ao poema. Assim, deixa-se subentendido (nos capítulos, nos exemplos, nos exercícios sugeridos pelas coleções) que, para que uma canção possa ser interpretada, a letra é suficiente. Até mesmo quando as obras tratam da musicalidade, esta se resume aos aspectos sonoros das letras 
(rimas, assonâncias, aliterações etc.), sem considerar que, em seu processo de produção, a origem de uma canção é o amálgama entre letra e melodia, criando elos que, se desfeitos, mudam a configuração do gênero textual.

É claro que a inserção da canção em um livro didático não pretende formar cancionistas, bem como não é isso que pretendemos ao insistirmos que a canção seja considerada em sua complexidade intersemiótica. No entanto, a formação de leitores críticos e sensíveis à constituição e à função social dos textos não pode prescindir de um exercício reflexivo em relação à materialidade dos gêneros, considerando suas particularidades constitutivas, discursivas e estéticas.

\section{Referências}

AMARAL, Emília; FERREIRA, Mauro; LEITE, Ricardo; ANTÔNIO, Severino. Novas palavras: $1^{\mathrm{o}}$ ano, $2^{\mathrm{a}}$ ed. São Paulo: FTD, 2013.

BRASIL. Guia de livros didáticos: PNLD 2015: língua portuguesa: ensino médio. Brasília: Ministério da Educação, Secretaria de Educação Básica. Brasília, 2014.

BRONCKART, Jean-Paul. Atividade de linguagem, textos e discurso: por um interacionismosócio-discursivo. São Paulo: Educ, 1999.

CANDIDO, Antonio. O direito à literatura. In: LIMA, Aldo (org); et al. $\mathbf{O}$ direito à literatura. Recife: Editora Universitária da UFPE, 2012.

CANDIDO, Antonio. O estudo analítico do poema. São Paulo: Humanitas, 1996.

CEREJA, William Roberto; MAGALHÃES, Thereza Cochar. Português: linguagens. São Paulo: Saraiva, 2013. 
COSTA, Nelson Barros da. As letras e a letra: o gênero canção na mídia literária. In: DIONÍSIO, Angela Paiva; MACHADO, Anna Rachel; BEZERRA, Maria Auxiliadora (org.). Gêneros textuais e ensino. São Paulo: Parábola, 2010.

LENINE. Meu amanhã (Intuindo o til). In: LENINE. Na pressão. Barueri, São Paulo: BMG Brasil, 1999. 1 CD.

MARCUSCHI, Luiz Antônio. Produção textual, análise de gêneros e compreensão. São Paulo: Parábola Editorial, 2008.

MARCUSCHI, Luiz Antônio. Gêneros textuais: definição e funcionalidade. In: DIONÍSIO, Ângela Paiva e al (org.). Gêneros textuais e ensino. Parábola, 2010.

PALAVRA (En)Cantada. Direção: Helena Solberg. Produção: David Meyer. Co-produção: Marcio Debellian. Roteiro: Diana Vasconcelos, Helena Solberg, Marcio Debellian. Rio de Janeiro: Biscoito Fino, 2009. 1 DVD, 84 min, cor.

TATIT, Luiz. Musicando a semiótica: ensaios. São Paulo: Annablume, 1997. 